Herz 2020 $45: 719-725$

https://doi.org/10.1007/s00059-020-05001-2

Received: 23 August 2020

Revised: 7 September 2020

Accepted: 27 October 2020

Published online: 20 November 2020

(c) Springer Medizin Verlag $\mathrm{GmbH}$, ein Teil von

Springer Nature 2020

\section{Introduction}

In late 2019, a cohort of patients presenting with pneumonia of varying acuity and unclear etiology in Wuhan, China, heralded the outbreak of coronavirus disease 19 (COVID-19). Coronaviruses are known to cause respiratory or intestinal infections in humans and animals [1].

Previous severe acute respiratory syndrome (SARS) beta-coronavirus infections have been associated with tachyarrhythmias and signs and symptoms of heart failure [2].

Other acute respiratory infections, including influenza, respiratory syncytial virus, and bacterial pneumonias, are well-known triggers for cardiovascular diseases (CVD) [3, 4].

According to data from previous coronavirus epidemics (SARS and Middle East respiratory syndrome, MERS), these viral infections led mainly to pulmonary complications such as pneumonia and acute respiratory distress syndrome [5, 6]. Nevertheless, these viruses were reported to cause direct myocardial injury with subsequent myocarditis [7-9].

The emergence of severe acute respiratory syndrome coronavirus 2 (SARSCoV-2), which causes COVID-19, rapidly developed into a pandemic, and a large number of infected patients have been reported to have underlying CVD [10, 11].

Although COVID-19 appears to have greater infectivity and lower mortality than SARS and MERS, many uncertainties remain regarding, e.g., its viral evolution, appropriate anti-viral treatment, and strategies for disease control.

\author{
Ahmed Saleh ${ }^{1}(\mathbb{D}) \cdot$ Akira Matsumori $^{2} \cdot$ Sherif Abdelrazek $^{3} \cdot$ Sara Eltaweel $^{3}$. \\ Amjad Salous ${ }^{1} \cdot$ Franz-Josef Neumann ${ }^{3} \cdot$ Matthias Antz $^{1}$ \\ ${ }^{1}$ Klinikum Braunschweig, Academic Hospital of Hannover Medical School, Braunschweig, Germany \\ ${ }^{2}$ Clinical Research Center, Kyoto Medical Center, Kyoto, Japan \\ ${ }^{3}$ University heart center Bad Krozingen, Bad Krozingen, Germany
}

\title{
Myocardial involvement in coronavirus disease 19
}

There are only scant published data regarding cardiovascular burden in the wake of viral epidemics. This study aimed to evaluate cardiac involvement in COVID-19.

\section{Methods}

\section{Study design and participants}

This prospective cohort study included 40 adult inpatients ( $\geq 18$ years old) at the Braunschweig Municipal Hospital (21 patients) and the Bad Krozingen Heart Center (19 patients) in Germany. Adult patients diagnosed with COVID19 in accordance with World Health Organization (WHO) interim guidance were included in the study.

The suspicion of COVID-19 infection was based on clinical presentation, contact to an active case with current infection, or having visited one of the known risk areas in China or Italy. Throat-swab specimens were obtained for detection of SARS-CoV-2 polymerase chain reaction (PCR) examination at the emergency department. Asymptomatic positive patients were sent home to self-quarantine. Clinically stable positive patients with mild to moderate symptoms were admitted to isolation wards adapted for COVID-19 patients. Admission to an intensive care unit (ICU; arranged for infected patients) for initially unstable COVID-19 patients or upon clinical deterioration was available for further management.

The criteria for discharge included resolution of fever without the use of antipyretic medication, clinical improve- ment of signs and symptoms, pulmonary imaging showing obvious resolution of inflammation, and clinical remission of respiratory symptoms. Patients were discharged according to the evaluation of the treating physician. Discharge was followed by mandatory self-isolation at home or in a safe place for 8 days after the onset of symptoms in the event of mild cases or for 14 days in severe cases, in compliance with the European Centre for Disease Prevention and Control recommendations [12].

Surveillance visits by family physicians and local medical offices, as well as monitoring via telephone or other electronic devices for further check-ups were implemented.

\section{Data collection}

Routine blood examinations included complete blood count, coagulation profile, serum biochemical tests (including renal and liver function, creatine kinase [CK], lactate dehydrogenase, and electrolytes), myocardial enzymes, serum ferritin, procalcitonin, N-terminal probrain natriuretic peptide (NT-proBNP), and immunoglobulin kappa and lambda. These parameters were recorded at hospital admission. Further follow-ups were performed based on clinical need. The authors only included the values at admission in their analysis. Chest radiographs or computed tomography (CT) scans were performed in all inpatients. A total of 21 patients with dyspnea or chest discomfort were examined with transthoracic echocardiography. Examinations were performed via a digital ultrasonic 
Table 1 Mean and standard deviation of troponin, N-terminal pro-brain natriuretic peptide (NT-proBNP), creatine kinase, free light chain immunoglobulins (FLC Ig) lambda and kappa, and D-dimer in relation to the laboratory reference range in patients with or without a history of known cardiac disease

\begin{tabular}{|c|c|c|c|c|c|}
\hline & Mean & SD & $\begin{array}{l}\text { No history of } \\
\text { cardiac disease } \\
\text { n. (\%) }\end{array}$ & $\begin{array}{l}\text { Known history of } \\
\text { cardiac disease } \\
\text { n. (\%) }\end{array}$ & Reference range \\
\hline Troponin $(\mathrm{pg} / \mathrm{ml})$ & 27.75 & 20.7 & $18(45)$ & $7(17.5)$ & $<14$ \\
\hline NT-proBNP $(p g / m l)$ & 1847.5 & $\begin{array}{l}2582.9 \\
\text { (median 682.5) }\end{array}$ & $20(50)$ & $7(17.5)$ & $<486$ \\
\hline Creatinine kinase (U/I) & 242.9 & $\begin{array}{l}254.3 \\
\text { (median 125.5) }\end{array}$ & $15(37.5)$ & $2(5)$ & $<190$ \\
\hline FLCIg lambda (mg/l) & 45.6 & 41.1 & $23(57.5)$ & $9(22.5)$ & $6.7-22.4$ \\
\hline FLClg kappa (mg/l) & 38.5 & 23.5 & $21(52.5)$ & $8(20)$ & $8.3-27.0$ \\
\hline$D$-dimer $(m g / l)$ & 2.3 & $\begin{array}{l}3.7 \\
\text { (median 1.09) }\end{array}$ & $21(52.5)$ & $12(30)$ & $<0.44$ \\
\hline
\end{tabular}

device system (Vivid 9 and Vivid 7, GE Vingmed Ultrasound, Horten, Norway) in harmonic mode $2.0 / 4.3 \mathrm{MHz}$, with a maximum frame per second (FPS) range of 64-112. Conventional echocardiography examination was performed including two-dimensional (2D) based $\mathrm{M}$-mode measures of cardiac chambers and ejection fraction (EF\%), pulsed and continuous wave Doppler studies, color Doppler study, and calculation of EF\% using Simpson's method. The examinations were conducted on the isolation wards or in the ICU by two certified echocardiography specialists, observing the requirements and technical specifications of personal protective equipment (PPE) [13].

Fever was defined as a tympanic temperature of at least $37.3^{\circ} \mathrm{C}$. The level of suspicion of COVID-19 infection was graded according to $\mathrm{CT}$ findings from very low, or COVID-19 Reporting and Data System (CO-RADS) 1 , to very high, or CO-RADS 5. CO-RADS is a categorical assessment scheme for pulmonary involvement of COVID-19 on non-enhanced chest CT developed by the Dutch Radiological Society [14]. All patients were categorized between CO-RADS 3 (unclear whether COVID-19 is present), CO-RADS 4 (CT abnormalities suspicious for COVID-19), or CO-RADS 5 (typical for COVID-19 infection).

\section{Statistical analysis}

Statistical analysis was performed using SPSS Statistics, version 25.0 (IBM Corporation, Armonk, NY). The categorical variables are expressed as numbers and percentages and were compared using the Chi-square test. Continuous data are expressed as mean \pm standard deviation (SD) and compared using a one-way analysis of variance (ANOVA) and a posthoc Tukey test. Independent predictors of mortality were determined using Cox proportional hazards regression models for all causes and cardiovascular disease. For all-cause mortality, age was forced into the model. $P<0.05$ was considered significant. Logistic regression analysis was used to analyze correlations between the severity of lung involvement based on CO-RADS classification and cardiac biomarkers and was demonstrated with scatter plot curves.

\section{Results}

This prospective study included 40 patients from two centers in Germany (the Municipal Hospital of Braunschweig and the Bad Krozingen Heart Center). Women accounted for $37.5 \%$ of the study cohort $(n=15)$. A total of 19 patients (47.5\%) had hypertension, while 11 had already been diagnosed with diabetes mellitus before admission. Of the studied group, 10 had already been previously diagnosed with cardiac disease (25\%). The mean age in the study group was $67 \pm 17$ years. In all, $62.5 \%$ of patients complained of fever upon admission, while 12 patients had a sore throat. Half of the cohort presented with dyspnea $(n=20)$ and 11 patients had chest pain prior to admission. Eight patients in the present cohort died due to their infection with COVID-19 (• Table 1).

\section{Cardiac manifestations}

NT-proBNP was elevated in 27 patients at admission. The mean value of NTproBNP was $1847.5 \pm 2582.9 \mathrm{pg} / \mathrm{ml}$ (median 682.5). Moreover, troponin $\mathrm{T}$ was positive in 25 patients, revealing a mean value of $27.75 \pm 20.7 \mathrm{pg} / \mathrm{ml}, 18$ of which had no prior history of cardiac disease. At the same time, elevated creatine kinase was noted in 17 patients (mean value $242.9 \pm 254.3 \mathrm{U} / \mathrm{l}$, median 125.5), 15 of which had no past history of cardiac disease. The levels of free light chain immunoglobulins (FLC Ig) lambda were measured; 32 patients with a mean value of $45.6 \pm 41.1 \mathrm{mg} / \mathrm{l}$ exhibited an elevation above the reference range (23 with no concomitant heart disease). FLCIgkappa had a mean value of $38.5 \pm 23.5 \mathrm{mg} / \mathrm{l}$ and was elevated in 29 patients (21 without known heart disease), with 33 patients showing increased D-dimer levels at a mean value of $2.3 \pm 3.7 \mathrm{mg} / \mathrm{l}$ (median 1.09). Of these patients, two had a history of thrombosis. One revealed a peripheral pulmonary embolism on thoracic $\mathrm{CT}$ and nine patients had a history of cardiac disease (• Table 2).

Cardiac troponin $\mathrm{T}$ was significantly higher in patients that were admitted to an ICU $(39.3 \pm 21.0 \mathrm{pg} / \mathrm{ml})$ in comparison to the patients that did not need intensive care admission $(20.8 \pm 17.5 \mathrm{pg} / \mathrm{ml}$; $p$-value 0.005). Correspondingly, the ICU patients showed statistically significant elevation of NT-proBNP and 
creatine kinase $(3695.9 \pm 3392.8 \mathrm{pg} / \mathrm{ml}$ and $408.2 \pm 297.2 \mathrm{U} / \mathrm{l})$ compared to non-ICU patients $(738.4 \pm 842.8 \mathrm{pg} / \mathrm{ml}$ and $143.8 \pm 162.1 \mathrm{U} / \mathrm{l} ; \quad p$-values $<0.01$ and 0.001 , respectively). Similarly, the FLC Ig lambda and kappa were significantly higher among the patients that required ICU management $(69.9 \pm 62.9 \mathrm{mg} / \mathrm{l}$ and $53.7 \pm 34.8 \mathrm{mg} / \mathrm{l})$, in contrast to patients admitted to normal wards $(33.9 \pm 16.6 \mathrm{mg} / \mathrm{l}$ and $31.2 \pm 10.0 \mathrm{mg} / \mathrm{l} ; \quad p$-values 0.008 and 0.003 respectively) (• Fig. 1 ; • Table 1 ).

Additionally, a significant correlation between the severity of pulmonary involvement, based on CO-RAD classification, and NT-proBNP was revealed $(\mathrm{r}=0.47, p=0.002)$. The correlation between the CT findings and troponin was less significant $(r=0.11, p=0.048)$. A further correlation was revealed between creatine kinase and lung CT $(r=0.46$, $p$ 0.003). Moreover, a weak correlation with FLC Ig kappa (r 0.14, $p=0.40$ ) was established, while no significant correlation with FLC Ig lambda was documented $(\mathrm{r}=0.06, p=0.71)$.

A total of 21 patients were examined by echocardiography as indicated from their clinical presentation. Five of 21 patients demonstrated reduced left ventricular EF $(<50 \%)$, four patients had elevated pulmonary artery systolic pressure (>25 mm Hg), and five patients revealed diastolic dysfunction with preserved systolic function (E/e' ratio $>15$; - Table 3 ). The electrocardiogram noted diffuse ST elevation in two patients without concomitant coronary artery stenosis (exclusion based on coronary angiography). First degree atrioventricular (AV) block with prolonged PR time was documented in eight patients $(20 \%)$ and prolonged QTc time in two patients before initiating antiviral therapy. No statistically significant difference was found between the mean values of PR time and QTc time in relation to ICU admission. The electrocardiographic and echocardiographic findings are shown in $\bullet$ Table 2.

\section{Discussion}

This study focused on the potential cardiac involvement of SARS-CoV-2 virus. It was based on laboratory parameters as

Herz 2020 - 45:719-725 https://doi.org/10.1007/s00059-020-05001-2

(c) Springer Medizin Verlag GmbH, ein Teil von Springer Nature 2020

\section{Myocardial involvement in coronavirus disease 19}

Abstract

Background. In late 2019, a cohort of patients presenting with pneumonia of unclear etiology in Wuhan, China, heralded the outbreak of coronavirus disease 19 (COVID-19). Previous severe acute respiratory syndrome (SARS) beta-coronavirus infections have been associated with tachyarrhythmias and signs and symptoms of heart failure. The emergence of SARS coronavirus 2 (SARSCoV-2), which causes COVID-19, has rapidly developed into a pandemic, and a large number of infected patients have been reported to have underlying cardiovascular disease.

Objective. Since there are only scant published data regarding cardiovascular burden in the wake of viral epidemics, this study aimed to evaluate cardiac involvement in COVID-19.

Material and methods. This prospective cohort study included 40 adult inpatients at two centers in Germany. Adult patients diagnosed with COVID-19 in accordance with World Health Organization (WHO) interim guidance were included in the study, which focused on the potential cardiac involvement of SARS-CoV-2. It was based on laboratory parameters as well as electro- and echocardiographic values to determine the impact of SARS-CoV-2 virus on heart tissues. Results. The conducted investigations confirmed the relationship between the presence of acute cardiac injury and COVID19.

Conclusion. Myocardial injury and impaired myocardial function due to COVID-19 are common; however, no correlation was established between cardiac laboratory or echocardiographic values and mortality. Cardiovascular monitoring upon COVID-19 infection is crucial to determine the burden of cardiac involvement.

Keywords

COVID-19 - Cardiovascular disease - SARS-

CoV-2 - NT-proBNP · Cardiac troponin T

\section{Myokardbeteiligung bei COVID-19}

\section{Zusammenfassung}

Hintergrund. Ende 2019 markierte eine Kohorte von Patienten aus Wuhan, China, die sich mit Pneumonie unklarer Ätiologie vorstellten, den Ausbruch der "coronavirus disease 19" (COVID-19). Frühere Severe-acuterespiratory-syndrome(SARS)- $\beta$-CoronavirusInfektionen waren mit Tachyarrhythmien sowie Zeichen und Symptomen der Herzinsuffizienz assoziiert. Nach dem ersten Auftreten des SARS-Coronavirus 2 (SARS-CoV-2), das COVID-19 auslöst, entwickelte sich rasch eine Pandemie. Bei einer Großzahl infizierter Patienten wird über eine bestehende HerzKreislauf-Erkrankung berichtet.

Ziel. Da die publizierten Daten zur kardiovaskulären Last im Rahmen von Virusepidemien nur spärlich sind, wurde in der vorliegenden Studie die kardiale Beteiligung bei COVID-19 untersucht.

Material und Methoden. In die prospektive Kohortenstudie wurden 40 erwachsene stationäre Patienten aus zwei deutschen Zentren eingeschlossen. Einschluss fanden erwachsene Patienten mit COVID-19-
Diagnose gemäß dem vorläufigen Leitfaden der Weltgesundheitsorganisation (WHO). Die Studie konzentrierte sich auf die potenzielle kardiale Beteiligung von SARS-CoV-2. Auf Basis von Laborparametern sowie elektround echokardiographischen Daten wurde der Einfluss des SARS-CoV-2-Virus auf Herzgewebe bestimmt.

Ergebnisse. Die Untersuchungen bestätigten die Beziehung zwischen dem Vorliegen akuter kardialer Schäden und COVID-19. Schlussfolgerung. COVID-19-bedingte Myokardschäden und Myokardfunktionsstörungen sind häufig, es fand sich jedoch keine Korrelation zwischen kardialen Labor- oder echokardiographischen Werten und der Mortalität. Eine kardiovaskuläre Überwachung bei COVID-19-Infektion ist von grundlegender Bedeutung, wenn die Last der kardialen Beteiligung bestimmt werden soll.

Schlüsselwörter

COVID-19 · Herz-Kreislauf-Erkrankung · SARSCoV-2 · NT-proBNP · Kardiales Troponin T 
Table 2 Demographics and basic characteristics of patients, together with radiological and electrocardiographic results

\begin{tabular}{|l|l|l|l}
$\begin{array}{l}\text { All patients } \\
(n=40)\end{array}$ & $\begin{array}{l}\text { No ICU admis- } \\
\text { sion } \\
(n=27)\end{array}$ & $\begin{array}{l}\text { ICU admission } \\
(n=13)\end{array}$ & $p$-Value \\
& & & \\
\hline
\end{tabular}

\section{Clinical manifestations}

\begin{tabular}{|c|c|c|c|c|}
\hline Age (years) & $67 \pm 17$ & $66 \pm 19$ & $69 \pm 15$ & 0.7 \\
\hline Female gender, $n$ (\%) & $15(37.5)$ & $14(51.9)$ & $1(7.7)$ & 0.013 \\
\hline Hypertension, $n(\%)$ & $19(47.5)$ & $14(51.9)$ & $5(38.5)$ & 0.511 \\
\hline Diabetes, $n(\%)$ & $11(27.5)$ & $4(14.8)$ & $7(53.8)$ & 0.02 \\
\hline $\begin{array}{l}\text { History of cardiac dis- } \\
\text { ease, } n(\%)\end{array}$ & $10(25)$ & $0(0)$ & $10(25)$ & 0.016 \\
\hline $\begin{array}{l}\text { Family history of cardiac } \\
\text { disease, } n(\%)\end{array}$ & $4(10)$ & $0(0)$ & $4(14.8)$ & 0.28 \\
\hline Temperature, ${ }^{\circ} \mathrm{C}$ & $38.4 \pm 1.6$ & $38.5 \pm 1.3$ & $38.4 \pm 1.5$ & 0.73 \\
\hline $\mathrm{O}^{2}(\%)$ & $89 \pm 5$ & $91 \pm 2$ & $84 \pm 7$ & 0.001 \\
\hline $\begin{array}{l}\text { Catecholamine therapy, } \\
n(\%)\end{array}$ & $7(17.5)$ & $0(0)$ & $7(53.8)$ & $<0.01$ \\
\hline $\begin{array}{l}\text { Mechanical ventilation, } \\
n(\%)\end{array}$ & $9(22)$ & $0(0)$ & $9(60)$ & $<0.01$ \\
\hline Mortality, $n(\%)$ & $8(20)$ & $4(14.8)$ & $4(30.8)$ & 0.4 \\
\hline $\begin{array}{l}\text { Duration of hospital stay } \\
\text { (days) }\end{array}$ & $14 \pm 9$ & $9 \pm 6$ & $21 \pm 8$ & $<0.01$ \\
\hline \multicolumn{5}{|l|}{ Clinical symptoms } \\
\hline Fever, $n(\%)$ & $25(62.5)$ & $15(55.6)$ & $10(76.9)$ & 0.17 \\
\hline Dyspnea, $n(\%)$ & $20(50)$ & $12(44.4)$ & $8(61.5)$ & 0.5 \\
\hline Sore throat, $n(\%)$ & $12(30)$ & $6(22.2)$ & $6(46.2)$ & - \\
\hline Chest pain, $n(\%)$ & $11(52.5)$ & $7(25.9)$ & $4(30.8)$ & 0.51 \\
\hline Cough, $n(\%)$ & $17(42.5)$ & $9(33.3)$ & $8(61.5)$ & 0.17 \\
\hline \multicolumn{5}{|l|}{ CT staging $(n=40)$} \\
\hline CO-RADS 3, n (\%) & $16(40)$ & $16(59.3)$ & $0(0)$ & \multirow[t]{3}{*}{0.001} \\
\hline CO-RADS 4, n (\%) & $10(25)$ & $4(14.8)$ & $6(46.2)$ & \\
\hline CO-RADS 5, n (\%) & $14(35)$ & $7(25.9)$ & $7(53.8)$ & \\
\hline \multicolumn{5}{|l|}{ Laboratory findings } \\
\hline CRP (mg/l) & $87.4 \pm 61.6$ & $58.6 \pm 42.5$ & $142.8 \pm 55.2$ & $<0.01$ \\
\hline $\begin{array}{l}\text { Leucocyte count } \\
(10 \mathrm{e} 3 / \mu \mathrm{l})\end{array}$ & $7.9 \pm 3.3$ & $7.7 \pm 3.9$ & $8.1 \pm 1.4$ & 0.71 \\
\hline Lymphocytes $(10 \mathrm{e} 3 / \mu \mathrm{l})$ & $1.7 \pm 1.8$ & $2.1 \pm 2.1$ & $1 \pm 0.5$ & 0.06 \\
\hline Thrombocytes $(10 \mathrm{e} 3 / \mu \mathrm{l})$ & $299.9 \pm 169.6$ & $305.1 \pm 168.5$ & $289.2 \pm 178.2$ & 0.8 \\
\hline Procalcitonin $(\mu \mathrm{g} / \mathrm{l})$ & $0.53 \pm 0.98$ & $0.49 \pm 1.1$ & $0.6 \pm 0.67$ & 0.7 \\
\hline CK (U/I) & $\begin{array}{l}242.9 \pm 254.3 \\
\text { (median 125.5) }\end{array}$ & $143.8 \pm 162.1$ & $408.2 \pm 297.2$ & 0.001 \\
\hline $\mathrm{CK}_{\mathrm{MB}}(\mathrm{U} / \mathrm{I})$ & $24 \pm 14.9$ & $20.5 \pm 8.9$ & $31.2 \pm 21.7$ & $<0.05$ \\
\hline Troponin (pg/ml) & $27.7 \pm 20.7$ & $20.8 \pm 17.5$ & $39.3 \pm 21$ & 0.005 \\
\hline NT-ProBNP (pg/ml) & $\begin{array}{l}1847.5 \pm 2582.9 \\
\text { (median 682.5) }\end{array}$ & $\begin{array}{l}738.4 \pm 842.8 \\
\text { (median 590.0) }\end{array}$ & $3695.9 \pm 3392.8$ & $<0.01$ \\
\hline D-dimer (mg/l) & $\begin{array}{l}2.3 \pm 3.8 \\
\text { (median 1.09) }\end{array}$ & $1.6 \pm 1.7$ & $3.8 \pm 6.0$ & 0.08 \\
\hline FLC Ig lambda (mg/l) & $45.6 \pm 41.1$ & $33.9 \pm 16.6$ & $69.9 \pm 62.9$ & 0.008 \\
\hline FLC lg kappa (mg/l) & $38.5 \pm 23.7$ & $31.2 \pm 10.0$ & $53.7 \pm 34.8$ & 0.003 \\
\hline Ferritin (ng/ml) & $\begin{array}{l}855.78 \pm 1332.4 \\
\text { (median 601.00) }\end{array}$ & $619.3 \pm 428.8$ & $\begin{array}{l}1345.6 \pm 2233 \\
\text { (median 596.00) }\end{array}$ & 0.1 \\
\hline $\operatorname{ALT}(\mathrm{U} / \mathrm{I})$ & $63.9 \pm 52.9$ & $56.7 \pm 39.8$ & $78.8 \pm 73$ & 0.24 \\
\hline Creatinine $(\mathrm{mg} / \mathrm{dl})$ & $0.8+0.2$ & $0.73+0.15$ & $0.89 \pm 0.23$ & 0.02 \\
\hline
\end{tabular}

well as electro- and echocardiographic values to determine the impact of SARS$\mathrm{CoV}-2$ virus on heart tissues. The conducted investigations confirmed the relationship between the presence of acute cardiac injury and COVID-19.

The authors' patients experienced myocardial injuries ( $45 \%$ of the study group): myocardial necrosis was suggested by increased troponin Tlevels, and myocardial functional disturbance by elevated NTproBNP, as well as disturbed left ventricular systolic and diastolic function. In addition to these findings, the existence of enhanced inflammatory biomarkers such as CRP, ferritin, and FLCs suggested that myocardial injury may be caused by inflammatory myocardial processes. NTproBNP showed significant correlation with the length of hospital management and the severity of pulmonary CT findings.

The electrocardiographic findings in these patients, such as ST elevation without reciprocal ST depression in the absence of acute coronary artery insult, and the conduction disturbances suggest further evidence of myocarditis, most likely due to direct viral invasion or immunemediated myocardial injury. The presence of myocardial interstitial oedema in acute viral myocarditis can lead to disturbance of both systolic and diastolic function, which was detected in $25 \%$ of the patients. Patients with myocarditis can show pulmonary hypertension in the acute course. Other compensatory mechanisms, such as right ventricular hypertrophy, need weeks or months to develop. The thrombogenic nature of COVID-19 may have led to peripheral pulmonary vasculature insults with acute elevated pulmonary pressure. This theory cannot be excluded, even though no central pulmonary embolisms were detected on thorax CT.

The results of univariate Cox proportional hazards analysis for laboratory biomarkers or echocardiographic parameters, possibly due to relatively small sample size, showed no significant independent prognostic value for mortality in the present COVID patients.

The myocardium may be infected by a wide variety of viruses $[15,16]$. In patients with moderate to severe heart 


\section{Table 2 (Continued)}

\begin{tabular}{|l|l|l|l}
$\begin{array}{l}\text { All patients } \\
(n=40)\end{array}$ & $\begin{array}{l}\text { No ICU admis- } \\
\text { sion } \\
(n=27)\end{array}$ & $\begin{array}{l}\text { ICU admission } \\
(n=13)\end{array}$ & $p$-Value \\
& & \\
\hline
\end{tabular}

\section{Electrocardiographic parameters}

\begin{tabular}{|c|c|c|c|c|}
\hline $\begin{array}{l}\text { Diffuse ST-segment } \\
\text { elevation, } n(\%)\end{array}$ & $2(5)$ & $1(4)$ & $1(6.7)$ & 1 \\
\hline Prolonged PR time, $n$ (\%) & $8(20)$ & $4(16)$ & $4(26.7)$ & 0.44 \\
\hline PR time (ms) & $181 \pm 25$ & $180 \pm 25$ & $182 \pm 26$ & 0.34 \\
\hline $\begin{array}{l}\text { Prolonged QTc time, } \\
n(\%)\end{array}$ & $2(5)$ & $0(0)$ & $2(13.3)$ & 0.14 \\
\hline QTc time (ms) & $436 \pm 31$ & $434 \pm 32$ & $438 \pm 28$ & 0.43 \\
\hline $\begin{array}{l}\text { Right bundle branch } \\
\text { block, } n(\%)\end{array}$ & $2(5)$ & $0(0)$ & $2(13.3)$ & 0.13 \\
\hline $\begin{array}{l}\text { Left bundle branch } \\
\text { block, } n(\%)\end{array}$ & $1(2.5)$ & $1(4)$ & $0(0)$ & 1 \\
\hline $\begin{array}{l}\text { New-onset atrial fibrilla- } \\
\text { tion, } n(\%)\end{array}$ & $2(5)$ & $1(4)$ & $1(6.7)$ & 1 \\
\hline \multicolumn{5}{|c|}{$\begin{array}{l}O^{2} \text { oxygen saturation, CO-RADS COVID-19 Reporting and Data System, CRP C-reactive protein, } \\
C K \text { creatine kinase, } C K_{M B} \text { creatine kinase mb-fraction, NT-ProBNP N-terminal pro brain natriuretic } \\
\text { peptide, } F L C \text { Ig free light chain immunoglobulin, ALT alanine aminotransferase, IL6 interleukin 6, } \\
S D \text { standard deviation }\end{array}$} \\
\hline
\end{tabular}

Table 3 Echocardiographic values in patients with positive coronavirus disease 19

\begin{tabular}{|c|c|c|c|c|}
\hline Echocardiographic parameters & $\begin{array}{l}\text { All patients } \\
(n=21)\end{array}$ & $\begin{array}{l}\text { No ICU ad- } \\
\text { mission }\end{array}$ & $\begin{array}{l}\text { ICU admis- } \\
\text { sion }\end{array}$ & \\
\hline Normal LV ejection fraction, $n$ (\%) & $16(40)$ & $10(40)$ & $6(40)$ & 0.09 \\
\hline Reduced LV ejection fraction, $n$ (\%) & $5(12.5)$ & $1(4)$ & $4(26.7)$ & 0.09 \\
\hline New significant valve lesions, $n$ (\%) & $0(0)$ & $0(0)$ & $0(0)$ & - \\
\hline $\begin{array}{l}\text { Elevated pulmonary systolic pres- } \\
\text { sure, } n(\%)\end{array}$ & $4(10)$ & $1(4)$ & $3(20)$ & 0.14 \\
\hline$L V$ left ventricular & & & & \\
\hline
\end{tabular}

failure $(\mathrm{EF}<45 \%)$ and inflammation in the Marburg registry, $42.1 \%$ were viruspositive [17].

In 2006, a study of patients diagnosed with SARS revealed that tachycardia was the most common finding (72\%) beside hypotension $(50 \%)$, bradycardia (15\%), transient cardiomegaly (11\%), and transient paroxysmal atrial fibrillation in only one patient $(0.8 \%)$ as a result of direct cardiac injury in the absence of underlying heart disease [2]. Another group aimed to characterize cardiac manifestations in the 2009 influenza pandemic (H1N1). In all, $46 \%$ of patients showed evidence of myocardial injury. Of 28 patients in whom an echocardiogram was clinically indicated, 20 had left ventricular systolic dysfunction. Of these, 14 patients were diagnosed as having myocarditis, with most (12 patients) developing this early on [18]. Fulminant myocarditis caused by the H1N1 strain of influenza was also reported [19]. Various studies described myocarditis related to other influenza forms [20-22]. Further reports linked MERS coronavirus (MERS-CoV) to myocarditis and severe left ventricular systolic dysfunction [9]. Furthermore, an animal model study clearly stated that viral RNA could be seen in cardiac tissue, implying direct cardiac pathology [23].

Shi et al. conducted a single-center cohort study at Wuhan University, China, and retrospectively included a total of 416 hospitalized patients with COVID-19. Approximately 82 patients (19.7\%) were reported to have cardiac injury. A higher mortality rate $(p<0.001)$ was noticed in patients with cardiac injury (51.2\%) than those without cardiac injury (4.5\%) [24]. To evaluate the association of underlying CVD and myocardial injury with fatal outcomes in COVID-19 patients, Guo et al. conducted a retrospective singlecenter study. Of a total of 187 patients with confirmed COVID-19, 52 (27.8\%) patients exhibited myocardial injury as indicated by elevated troponin $\mathrm{T}$ levels [25]. Likewise, myocardial injury proved by troponin $\mathrm{T}$ elevation was determined in $45 \%$ of the present cohort. Similar to the current study, the authors did not observe any significant correlation between troponin T and NT-proBNP in relation to mortality [25].

Case reports have depicted the cardiac involvement of COVID-19 infection. The diagnosis of myocarditis was established upon troponin $\mathrm{T}$ and NTproBNP elevation and was confirmed in one case through echocardiography and in the other with cardiac MRI [26, 27]. Another group from New York, USA, identified ST-segment elevation in 18 patients infected with COVID-19. Noncoronary myocardial injury was noted in 10 patients indicating myo/pericarditis [28].

The authors did not detect any ventricular arrhythmias or sudden cardiac death (SCD) in patients under monitor surveillance. The proportion of SCD caused by myocarditis has been reported as ranging from $1 \%$ to $14 \%$ of all SCD $[29,30]$.

Elevation of FLC kappa and lambda in the current patient cohort suggests that the clones of B lymphocytes and plasma cells that produce FLCs may be activated in COVID-19 patients, although the number of lymphocytes were decreased. However, there were contradictory observations of FLC in heart failure, which may partly reflect the different FLC assays used [31, 32].

\section{Limitation}

The number of patients included in this study was relatively small, which did not allow proper monitoring of the prognostic value of various cardiac parameters for mortality risk. Given the difficulties associated with performing myocardial biopsy in COVID-19 patients, pathological diagnosis remains to be clarified. The authors cannot exclude a possible sample selection bias due to a discrepancy be- 


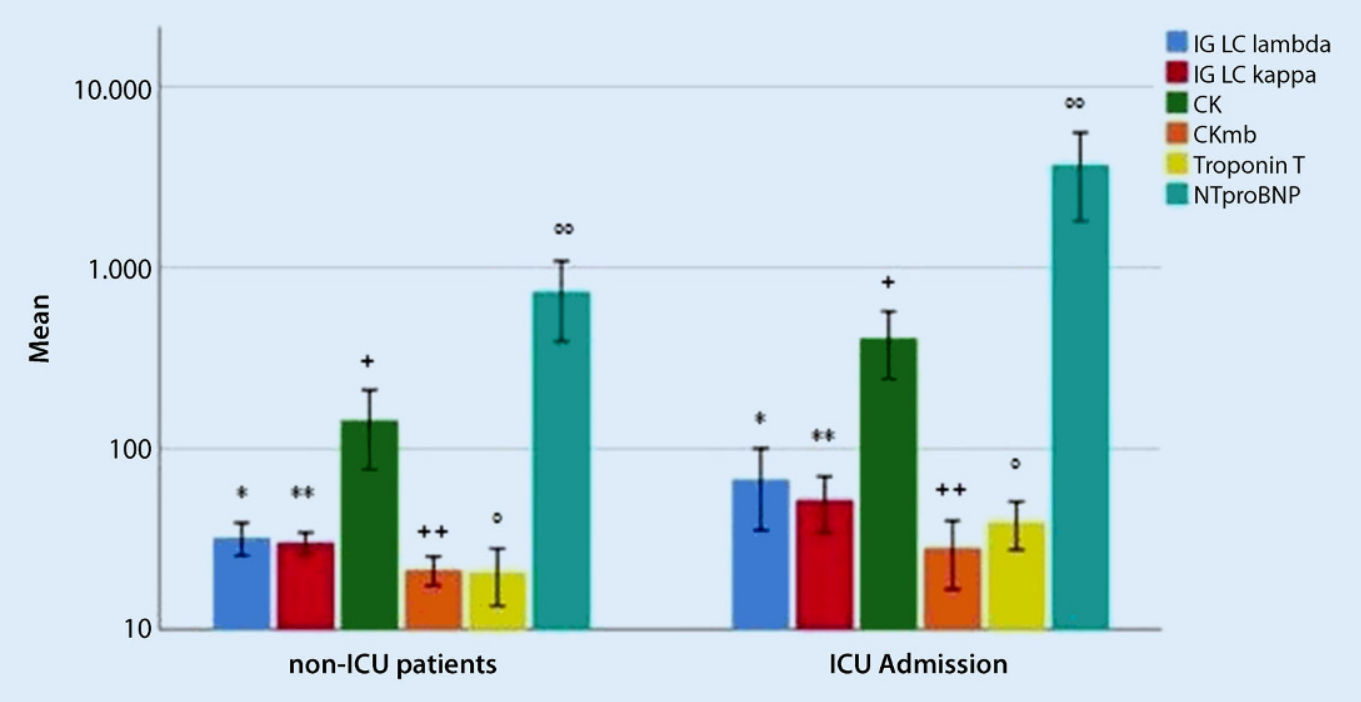

Fig. $1<$ Comparison of mean values and standard deviation of cardiac laboratory parameters in relation to intensive care unit (ICU) admission. ${ }^{*} p$-Value 0.008 , ${ }^{*} p$-value $0.003,+p$-value $0.001,++p$-value $<0.05$, ${ }^{\circ} p$-value $0.005,{ }^{\circ} p$-value $<0.01$

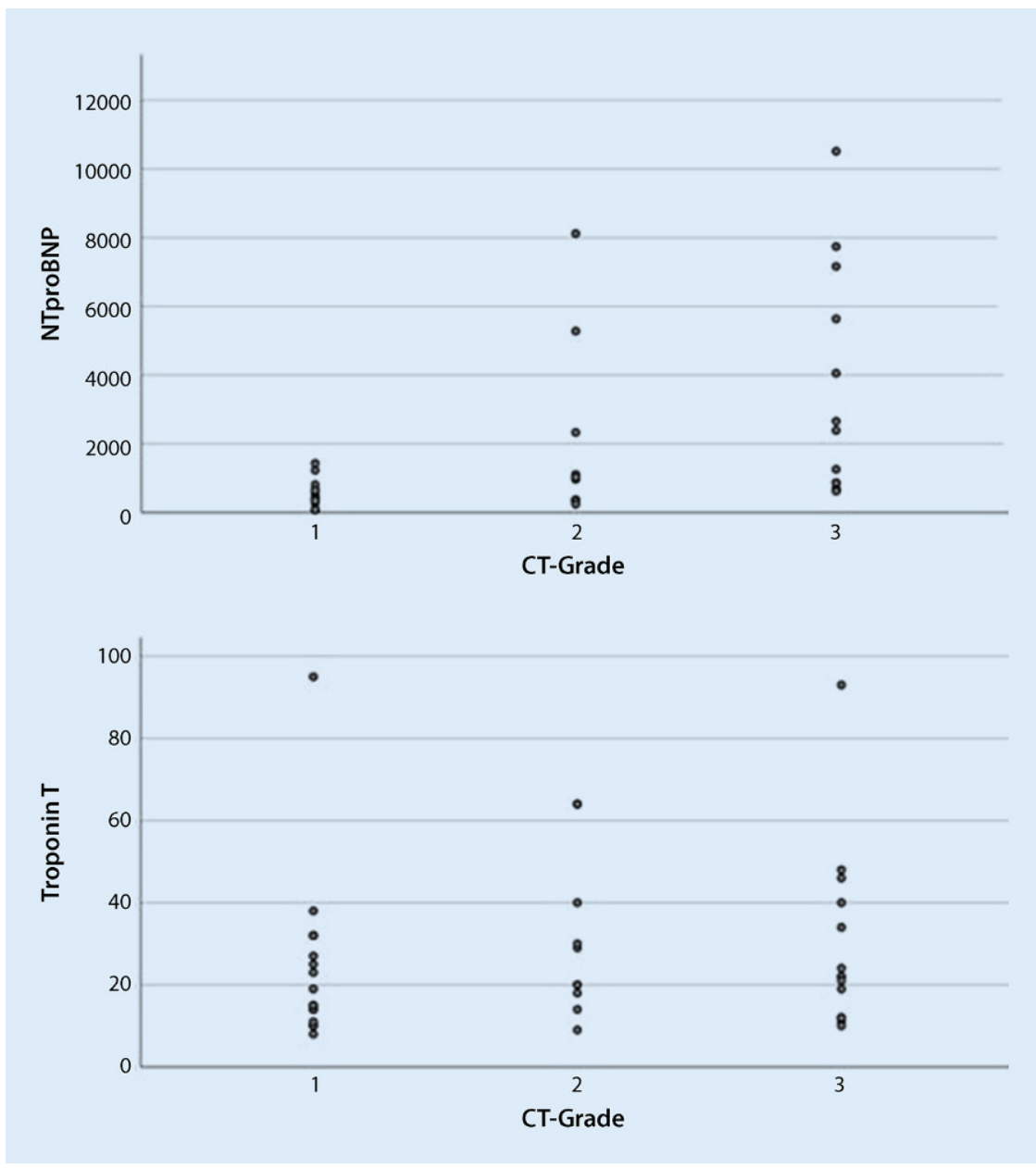

Fig. $2 \Delta$ Correlation of N-terminal pro-brain natriuretic peptide (NTproBNP) and troponin T to computed tomography $(C T)$ grading using sinple scatter tween the two recruiting centers (a heart center and a municipal hospital).

\section{Conclusion}

Myocardial injury and impaired myocardial function due to COVID-19 are common. Patients with elevated cardiac parameters such as NT-proBNP and cardiac troponin in the absence of a known history of heart disease are at higher risk for ICU admission. No correlation was established between cardiac laboratory or echocardiographic values and mortality. Cardiovascular monitoring upon COVID-19 infection is crucial to determine the burden of cardiac involvement.

\section{Corresponding address}

\section{Ahmed Saleh}

Klinikum Braunschweig, Academic Hospital of Hannover Medical School

Braunschweig, Germany

salehcardio@hotmail.com

\section{Compliance with ethical guidelines}

Conflict of interest. A. Saleh, A. Matsumori, S. Abdelrazek, S. Eltaweel, A. Salous, F.-J. Neumann, and M. Antz declare that they have no competing interests.

All procedures performed in studies involving human participants or on human tissue were in accordance with the ethical standards of the institutional and/or national research committee and with the 1975 Helsinki declaration and its later amendments or 
comparable ethical standards. Informed consent was obtained from all individual participants included in the study.

\section{References}

1. Cheng VCC, Lau SKP, Woo PCY, Yuen KY (2007) Severe acute respiratory syndrome coronavirus as an agent of emerging and reemerging infection. Clin Microbiol Rev 20(4):660-694. https://doi.org/ 10.1128/CMR.00023-07

2. Yu CM, Wong RS, Wu EB et al (2006) Cardiovascular complications of severe acute respiratory syndrome. Postgrad Med J 82(964):140-144. https:// doi.org/10.1136/pgmj.2005.037515

3. Cowan LT, Lutsey PL, Pankow JS, Matsushita K, Ishigami J, Lakshminarayan K (2018) Inpatient and outpatient infection as a trigger of cardiovascular disease: the ARIC study. J Am Heart Assoc 7(22):e9683-e9683. https://doi.org/10.1161/ JAHA.118.009683

4. Madjid M, Miller CC, Zarubaev VV et al (2007) Influenza epidemics and acute respiratory disease activity are associated with a surge in autopsyconfirmed coronary heart disease death: results from 8 years of autopsies in 34,892 subjects. Eur Heart J 28(10):1205-1210. https://doi.org/10. 1093/eurheartj/ehm035

5. Ksiazek TG, Erdman D, Goldsmith CS (2003) A novel coronavirus associated with severe acute respiratory syndrome. $\mathrm{N}$ Engl J Med 15(348):1953-1966

6. Van Boheemen ZAM, Bestebroer STM (2012) Isolation of a novel coronavirus from a man with pneumonia in Saudi Arabia. N Engl J Med 367:1814-1820

7. Ukimura A, Satomi H, Ooi Y (2012) Myocarditis associated with influenza A H1N1pdm2009. Influenza Res Treat 2012:1-8

8. Rao S, Sasser W, Diaz F (2014) Coronavirus associated fulminant myocarditis successfully treated with intravenous immunoglobulin and extracorporeal membrane oxygenation. Chest 146(4):336A. https://doi.org/10.1378/chest. 1992018

9. Alhogbani T (2016) Acute myocarditis associated with novel Middle East respiratory syndrome coronavirus. Ann Saudi Med 36:78-80

10. Dhainaut J-F, Claessens Y-E, Janes J, Nelson DR (2005) Underlying disorders and their impact on the host response to infection. Clin Infect Dis 41(suppl 7):S481-S489. https://doi.org/10.1086/ 432001

11. Fauci AS, Lane HC, Redfield RR (2020) Covid-19: navigating the uncharted. N Engl J Med. https:// doi.org/10.1056/NEJMe2002387

12. European Centre for Disease Prevention and Control (2020) Guidance for discharge and ending isolation in the context of widespread community transmission of COVID-19, 8 April 2020. ECDC, Stockholm

13. Advice on the use of masks in the community, during home care, and in health care settings in the context of COVID-19: WHO interim guidance (19 March 2020).

14. Prokop M, van Rees Vellinga T, The "COVID19 Standardized Reporting" Working Group of the Dutch Radiological Society (2020) CORADS-A categorical CT assessment scheme for patients with suspected COVID-19: definition and evaluation. Radiology 296(2):E97-E104
15. Matsumori A (2003) Cardiomyopathies and heart failure. Biomolecular, infectious and immune mechanisms. In: Matsumori A (ed) Cardiomyopathy and heart failure. Kluwer Academic Publishes, Boston, Dordrecht, London, pp 1-15

16. Saleh A, Matsumori A, Negm H, Fouad H, Hamdy E (2011) Assessment of cardiac involvement of hepatitis $C$ virus; tissue Doppler imaging and NTproBNP study. JSaudi Heart Assoc 23:217-223

17. Kuhl U, Pauschinger $M$, Noutsias M et al (2005) High prevalence of viral genomes and multiple viral infections in the myocardium of adults with "idiopathic" left ventricular dysfunction Circulation 111(7):887-893

18. Binila Chacko JVP, Pichamuthu K, Ramakrishna K, Moorthy M, Karthik R, John G (2012) Cardiac manifestations in patients with pandemic $(\mathrm{H} 1 \mathrm{~N} 1)$ 2009 virus infection needing intensive care. J Crit Care 27(1):106.e1-106.e6

19. Al-Amoodi M, Kavitha Rao, Seshu Rao, Brewer JH Magalski A, Chhatriwalla AK (2010) Fulminant myocarditis due to H1N1 influenza. Circ Heart Fail 3:e7-e9

20. Greaves K,Oxford JS, Price CP (2003)The prevalence of myocarditis and skeletal muscle injury during acute viral infection in adults: measurement of cardiac troponins I and T in 152 patients with acute influenza infection. Arch Intern Med 163:165-168

21. Connolly AM, Salmon RL, Lervy B (1993) What are the complications of influenza and can they be prevented? Experience from the 1989 epidemic of $\mathrm{H} 3 \mathrm{~N} 2$ influenza $\mathrm{A}$ in general practice. BMJ 306:1452-1454

22. Ison MG, Campbell V, Rembold C (2005) Cardiac findings during uncomplicated acute influenza in ambulatory adults. Clin Infect Dis 40:415-422

23. Agrawal AS, Garron T, Tao X, Peng BH, Wakamiya M Chan TS et al (2015) Generation of a transgenic mouse model of Middle East respiratory syndrome coronavirus infection and disease. J Virol 89:3659-3670

24. Shi S, Qin M, Shen B et al (2020) Association of cardiac injury with mortality in hospitalized patients with COVID-19 in Wuhan, China. JAMA Cardiol 5(7):802-810. https://doi.org/10.1001/ jamacardio.2020.0950

25. Guo T, Fan Y, Chen M et al (2020) Cardiovascular implications of fatal outcomes of patients with coronavirus disease 2019 (COVID-19). JAMA. https://doi.org/10.1001/jamacardio.2020.1017

26. Zeng JH, Liu YX, Yuan J et al (2020) First case of COVID-19 infection with fulminant myocarditis complication: case report and insights. Infection. https://doi.org/10.1007/s15010-020-01424-5

27. Inciardi RM, Lupi L, Zaccone G et al (2020) Cardiac involvement in a patient with coronavirus disease 2019 (COVID-19). JAMA Cardiol. https://doi.org/ 10.1001/jamacardio.2020.1096

28. Bangalore S, Sharma A, Slotwiner A (2020) STsegment elevation in patients with Covid-19-A case series. N Engl J Med 382:2478-2480. https:// doi.org/10.1056/NEJMc2009020

29. Wisten A, Krantz P, Stattin E-L (2017) Sudden cardiac death among the young in Sweden from 2000 to 2010: an autopsy-based study. Europace 19:1327-1334

30. Bagnall RD, Weintraub RG, Ingles J (2016) A prospective study of sudden cardiac death among children and young adults. N Engl J Med 374:2441-2452

31. Matsumori A, Shimada T, Nakatani E, Shimada M, Tracy S, Chapman NM, Drayson MT, Hartz VL, Mason JW (2020) Immunoglobulin freelight chains as an inflammatory biomarker of heart failure with myocarditis. Clin Immunol 217:108455. https:// doi.org/10.1016/j.clim.2020.108455

32. Jackson CE, Haig C, Welsh P, Dalzell JR, Tsorlalis IK, McConnachie A, Preiss D, McInnes IB, Sattar N, Petrie MC, Gardner RS, McMurray JJ (2015) Combined free light chains are novel predictors of prognosis in heart failure. JACC Heart Fail 3:618-625 